https://doi.org/10.46344/JBINO.2021.v010i01.35

\title{
A CASE STUDY - MANAGEMENT OF YAVANA PIDIKA WITH MAHAMANJISTHADI KHADA \& GANDHAKA MALAHARA
}

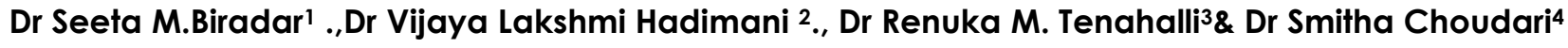 \\ 'Associate Professor \& Head Dept. of Roganidana, BLDEA'S AVS Ayurveda Mahavidyalaya, Vijayapur, Karnataka. \\ ${ }^{2}$ Assistant Professor ,Dept.of Shalya, BLDEA'S AVS Ayurveda Mahavidyalaya, Vijayapur, Karnataka \\ 3Professor \& Head, Dept.of Samhita Siddhanta, BLDEA'S AVS Ayurveda Mahavidyalaya, Vijayapur, Karnataka \\ ${ }^{4}$ Assistant Professor Dept. of Kayachikitsa, BLDEA'S AVS Ayurveda Mahavidyalaya, Vijayapur, Karnataka
}

\section{ABSTRACT}

Unhealthy lifestyle has caused major problem for Yavana pidika(acne vulgaris).It is the most common troublesome and frustrating skin care probl em for the people around the world. It is caused due to Kapha, Vata and Rakta Dhatu involving Rasavaha and Raktavaha Srotas. Acne vulgaris is a disease of the pilosebaceous follicle characterized by noninflammatory (open and closed comedowns) and inflammatory lesions (papules, pustules, and nodules). There are four major factors involved in the disease production viz. increased sebum production, cornification of pilosebaceous ducts, microbial involvement and inflammation. This condition is found commonly in puberty.Acharya Susruta has discussed mukhdooshika (yavanapidika) in the context of Kshudra rogas. Here in this case treatment modalities were applied, internally Manjisthadi khada as Raktha dhatu shodhaka and Gandhara malahara for healing of the pidika is administered.

Keywords-; yavanapidika,manjisthadi khada,vata,kapha,acne vulgaris. 


\section{INTRODUCTION}

Face is the index of mind.The yavana pidika as it results in disfigurement of physical and psychological status of an individual by manifesting in the important part of the body i.e face.According to Susruta,Yavanpidika is defined as शाल्मलीकण्टकप्रख्याः कफमारुतशोणितैः। जायन्ते पिडका यूनां वक्त्रे या मुखदूषिकाः | |३९। | (sU .ni $13 / 39)^{1}$

Shalamali kantaka like eruptions toon the face due to vitiation of kapha, vata and raktha,characterised saruja,Ghana,Medogarbha known as Mukhadushika or Yavanapidika or Tarunya pidika.In Ayurveda various treatment principles for Yavanapidika are explained like administration of drugs internally, external application of drugs, Virechana,Rakthamokshana and so on. In Ayurveda, there are many herbs described members. Menstruation was irregular. On local examination shows multiple which has excellent Vranaropak or healing properties. Getting clues from these, local application of Gandhak Malahar has been used in case of Yavanapidika.

\section{Case report;}

A 26years of female patient came at Harsh Ayur clinic, in the month of october2020 with the complaints of multiple small elevated scattered lesions over face and back, lots of pores on the check area of her face with dark spots after disappearance of the lesion for 6 months to lyear. She got no history of allergy, asthma. She took lots of cosmetics and herbal products for her fairness. She is married for $7 y$ rs and has one male healthy child of $5 y$ rs. She never took any contraceptive method. She took lots of antibiotics and anti-acne cream by the Dermatologist for 2yrs. There was no history of acne disease in her family

papulopustular lesions over face, neck and back. 
Physically investigated: Under Magnifying glass there were black head and white head comedons (which are the cardinal feature of acne vulgaris). There was no pain and itching sensations. On Wood's Lamp examination shows there were huge number of "Propionebacterium acne" organism present over the acne comedons, hyperpigmentation in the acne remission area, large pores due to acne scar. On General examination there was no abnormality detected. On Systemic examination shows her all the vital functions were normal.

Clinical symptoms presented by Patient are as follows;

Ruja/Pain

Daha/burning

Kandu/ltching

Pidika
Clinically investigated: Her $\mathrm{CBC}$ count was normal, blood Sr. Testosterone was normal (15-70mg/dL), USG of whole abdomen was normal, Slight changes in Lutenizing hormone, Follicle stimulating hormone were noted.

Previous treatment has taken: She was treated by antibiotics like Cap Doxycyclin 50-100mg (orally), Cap Tetracyclin 500mg (orally), Tab Azythromycin 500mg (orally), Erythromycine Iotion (locally), Clindamycine lotion (locally), Anti-Acne like Adapolen cream, Benzyle Peroxidase cream, Retinoic acid cream. Patient was treated by these medicines for more than one year.

Prognosis: She was not completely cured. Started combination: ;

Patient was given following treatment

1. Internally -MahaManjisthadi khada520ml

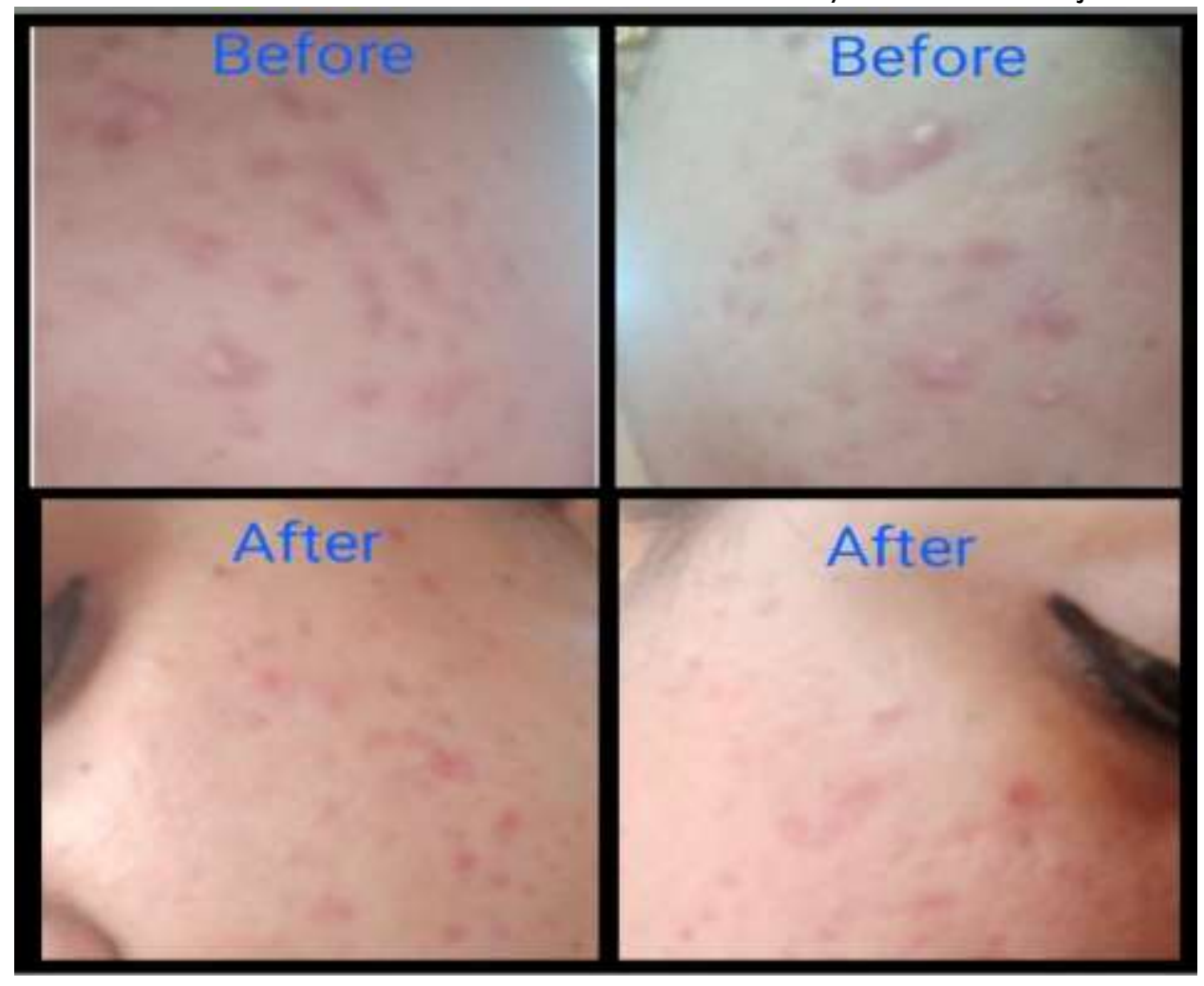


bid daily after food followed by ushnodaka for 10days
2. Externally- Gandhaka malahara lepa daily in night advised.
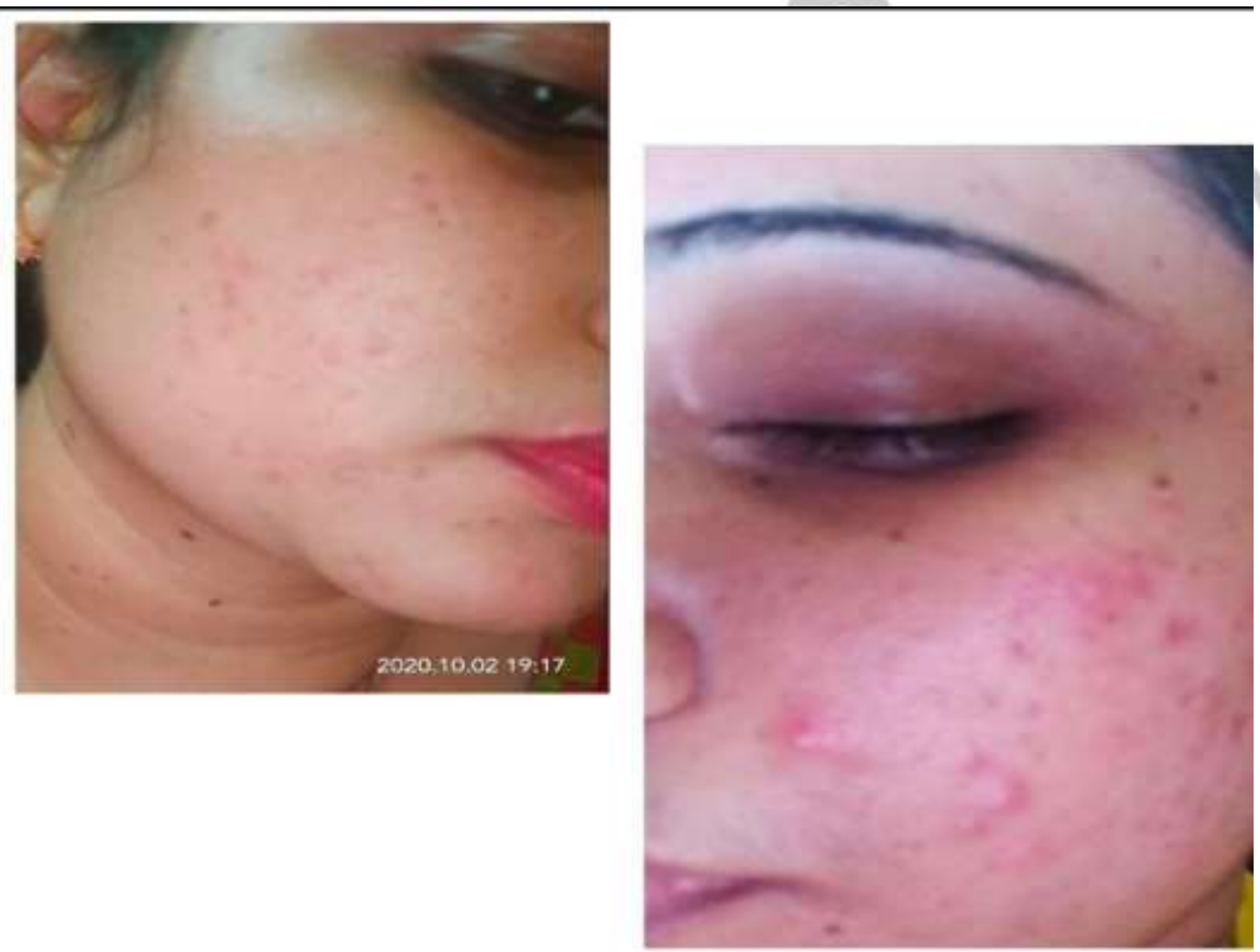


\section{Discussion}

Yavana pidika is affected on the face, all wants to look beautiful especially younger generation.Its an psychological disfigurement affecting mentally in youngsters. Here in this case MahaManjisthadi khada is selected for treatment, as Yavanapidika is due to dusti of Raktha dhatu it helps for purification of blood acts as Raktha shodhaka.It also balances the pitta dosha resulting in lightening of skin complexion and healing of comedones. According our Acharyas Mahamanjisthadi is best raktha shodhaka and its pallatablity is also good suits all prakrutis.Gandhaka malahara is indicated in skin diseases according to our classics.Hence in this patient I have administered Gandhaka malahara for application for a period of 10days.During the period of 10 days their was no any side effects noted by gandhaka malahara .After 10 days when patient came for follow up their was tremendous changes noted on the face, patient had satisfying smile on the face. Their was complete absence of itching, reduction of size of pustules noted, complete healing of pidikas with scars.

\section{Conclusion}

It was seen that Mahamanjisthadi khada and Ghandhaka malahara proved effective in Yavana pidika (acne vulgaris) Mahamanjisthadi khada acts as Srotoshodaka whereas The obtained results and primary observations have shown very encouraging outcomes. Thus, Gandhak Malahara is highly effective, safe, easily 
available, cheap treatment for Yavanapidika and proves best treatment for Yavana pidika. Gandhaka malahara proved to be healing effect .

\section{References}

1. Murthy K.R. Shrikantha, Sushruta, Voll, Dalhana on Nidan sthan 13/1, Chaukhambha oreintalia, Varanasi, 2004; 282-6

2. Sharangdhara,Madhyamakhanda2:137140 Hindi commentary

by BrahmanandaTripathi, Varanasi, SharangdharSamhita, ChaukhambaSurbha ratiPrakashana 2015.

3. Shastri Dharmanand, Bhaishajya Ratnavali, Hindi Commentary, Motilal Banarsidas publication, Varanasi, 4th Edition.

4. Shastri Kashinath, Rasa Tarangini 8/63-65, Motilal Banarsidas publication, Varanasi, 4th Edition, 2004; 186.
5. Murthy K.R. Shrikantha, Sushruta, Voll, Dalhana on Nidan sthan 13/39, Chaukhambha oreintalia, Varanasi, 2004; 282-6

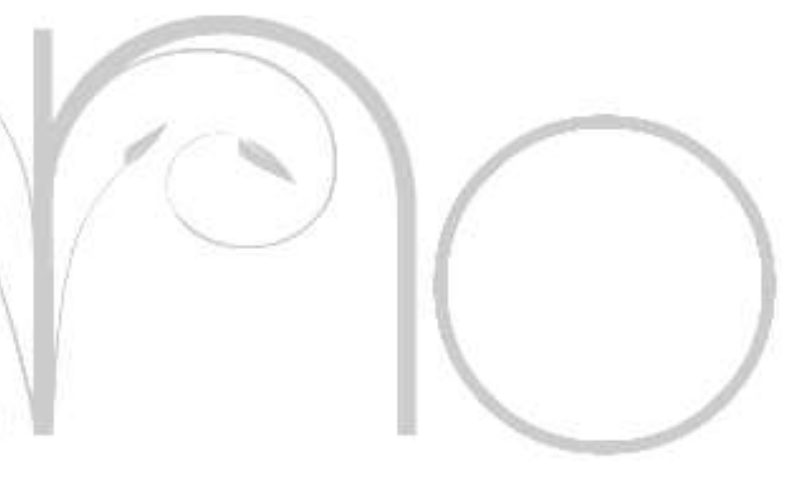

